\title{
Nice one Arthur
}

\section{MY NAME IS DAPHNE FAIRFAX: A MEMOIR ARTHUR SMITH \\ Hutchinson, London, 2009 pp392, £18.99, ISBN 9780091921033}

Arthur Smith is one of Britain's bestknown comedians and comedy writers. $\mathrm{He}$ opens some of his routines with 'My name is Arthur Smith, unless there's anybody here from Streatham tax office, in which case I'm Daphne Fairfax' hence the title of this book. Smith has written an affectionate and affecting account of growing up in post-war southeast London, in a close-knit family (which, for added medical interest, includes his brother Richard Smith, the previous and excellent editor of the $B M J$ ) and launching into a successful career as a stand-up comic, compere, and writer. The meat of the book describes how Smith ricocheted to the top, bouncing about between relationships, gigs, parties and more parties and, latterly, his ambivalent relationship with television. The pages are full of illuminating and quirky insights into Britain in the 70s and 80s, the Edinburgh Festival, the 'alternative' comedy circuit and the bizarre characters that inhabited these worlds. Further medical interest, presaged at the beginning of the book, arises when Smith's two-hander with alcohol ends in near-fatal necrotising pancreatitis and, subsequently, diabetes.

Arthur Smith is as good to read as he is to listen to - his writing is fresh, funny, and free of convention and stereotype. $\mathrm{He}$ tells, as you might expect, a good story and many of his exploits at the Edinburgh Fringe and the London clubs are hilariously memorable. $\mathrm{He}$ is selfdeprecatory in a slightly assertive way, extremely generous to his fellow artistes, and unwaveringly, touchingly respectful and grateful to his parents. His policeman father, Syd, sounds terrific (and, unless I missed it, Smith has managed to avoid using the term 'diamond geezer' to describe him, no matter how appropriate it might have been). I wish that his editor had taken a slightly harder line with some of the footnotes and self-referential quips that occasionally disturb the flow. There is a particularly good one on page 89 . Smith was in Paris trying to develop his student revolutionary persona (and teaching English to the President's son) at the time of Franco's death. The footnote says that 'Spanish dockers kept the dictator alive weeks after his body had given up'. Franco wasn't embalmed in a shipyard I checked.

Smith went back to Paris for his 50th birthday party, complete with Leonard Cohen karaoke room. The much-missed Linda Smith was the last person to leave the dance floor. Life-affirming is an overworked phrase, but describes this amiable memoir pretty well.

\section{Roger Jones}

DOI: 10.3399/bjgp09X453693 